\title{
Acknowledgment to Reviewers of JDB in 2020
}

\section{$J D B$ Editorial Office}

Citation: JDB Editorial Office. Acknowledgment to Reviewers of JDB in 2020. J. Dev. Biol. 2021, 9, 4 https://doi.org/10.3390/jdb9010004

Published: 29 January 202

Publisher's Note: MDPI stays neutral with regard to jurisdictional claims in published maps and institutional affiliations.

\section{(i)}

Copyright: (C) 2021 by the author. Licensee MDPI, Basel, Switzerland. This article is an open access article distributed under the terms and conditions of the Creative Commons Attribution (CC BY) license (http://creativecommons.org/licenses /by/4.0/).

MDPI AG, St. Alban-Anlage 66, 4052 Basel, Switzerland

Peer review is the driving force of journal development, and reviewers are gatekeepers who ensure that $J D B$ maintains its standards for the high quality of its published papers. Thanks to the cooperation of our reviewers, in 2020, the median time to first decision was 15.1 days and the median time to publication was 38 days. The editors would like to express their sincere gratitude to the following reviewers for their precious time and dedication, regardless of whether the papers were finally published:

Ackley, Brian

Ales, Cvekl

Armant, Olivier

Ashe, Alyson

Atukorallaya, Devi

Begemann, Gerrit

Bialecka, Monika

Bosveld, Floris

Brites, Pedro

Brunne, Bianka

Cagnin, Stefano

Chelmonska-Soyta, Anna

Ching, Tsui-Ting

Cifuentes, Daniel

Costa, Viviana

Crisponi, Laura

Dasgupta, Subham

Dash, Soma

Dawson, Paul

De La Cova, Claire

Denham, Mark

Dunnwald, Martine

Duprez, Delphine

Durand, Béatrice C.

Dworkin, Sebastian

Everman, Elizabeth

Fish, Jennifer L.

Giantsis, Ioannis

Gogal, Robert M.

Grunow, Bianka

Haenold, Ronny

Henry, Clarissa

Hiepen, Christian

Honore, Stephane

Hurley, James B.
Kanczler, Janos M.

Kerosuo, Laura

Khodanovich, Marina

Knudsen, Thomas B.

Kolesnikova, Tatyana

Krams, Indrikis

Kumar, Justin

Kwan, Kristen

Lees, Simon J.

Letra, Ariadne

Levi, Giovanni

MacNeil, Lesley T.

Magarlamov, Timur Yu.

Maspero, Cinzia

Mccarthy, John J.

McClurg, Urszula

Menzorov, Aleksei G

Mitani, Shohei

Morona, Ruth

Navarro, Nicolas

Navascues, Joaquin De

Olson, Eric

Peronnet, Frederique

Pettitt, Jonathan

Philp, Nancy J.

Polesello, Cédric

Pons, Sebastian

Pruyne, David

Qazi, Khaleda Rahman

Ravanidis, Stylianos

Reddy, Sakamuri

Reynolds, Christian

Richter, Wito

Robin, Nathaniel H.

Rogers, Melissa B. 
Saint-Jeannet, Jean-pierre

Sander, Veronika

Schellino, Roberta

Schlatt, Stefan

Sobierajska, Katarzyna

Soto, Martha C.

Sparagna, Genevieve C.

Steiner, Florian A.

Strathdee, Douglas

Tan, Tiong Yang
Tozer, Samuel

Tse, William K.F.

Velasco, Iván

Wake, David B.

Wartiovaara, Kirmo

Watt, Kristin

Wicky Collaud, Chantal

Woollard, Alison

Yetnikoff, Leora

Zhao, Hui 